
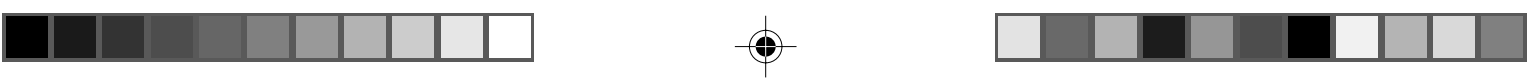

\title{
ADRIËNNE HEIJNEN
}

\section{STREGKODER, SPAREGRISE OG BARNEDÅB}

\author{
Det islandske selv i entreprenørskab og navngivning
}

Forskellige forskere (fx Geertz 1984; Dumont 1985; Strathern 1988; Barraud 1994; Mageo 2003) har gjort os opmærksom på, at ,personen“ “ $i$ den ikke-vestlige verden ikke kan tolkes på samme måde som individet i den vestlige verden, men snarere skal betragtes - med Stratherns ord - som „dividual“, den relationelle person (Strathern 1988). En modsat tendens i nutidens antropologi er at nedbryde enhver skelnen mellem det moderne og præmoderne eller det vestlige og ikkevestlige selv (fx Ewing 1990; Hornborg 1998:3; Spiro 1993). Herfra udspringer udtalelser som „vi har altid været kapitalister“(Friedman 1997; jf. Hornborg 1998) og analyser, som påpeger det rationelle og individualistiske i personopfattelser i ikke-vestlige samfund (fx Oxfeld 1992). Ideen, at den vestlige person er et individ, som opnår status som „komplet“ medlem af sit samfund igennem sine egne handlinger og ikke på baggrund af sociale relationer, er dog kun diskuteret $\mathrm{i}$ meget begrænset omfang inden for antropologien.

Denne artikel tager udgangspunkt i det islandske samfund, som udfordrer antagelsen af det vestlige individualistiske individ. De sidste par år har islændingene overrasket med dristige investeringer på det globale marked. I artiklens første del etableres argumentet, at islændingenes personopfattelse, som den kommer til udtryk i diskursen omkring islandsk entreprenørskab, ${ }^{1}$ er stereotypisk moderne og vestlig. Derefter dekonstrueres dette argument ved at præsentere en analyse af personopfattelsen, som den fremstår i islandske praksisser af navngivning af børn. Analyserne, som er bygget på min ph.d.-afhandling Icelandic Dream Sharing (2005) og på mit nye forskningsprojekt (påbegyndt efteråret 2006) om den såkaldte útrás, den islandske globale handelsrejse, viser, hvordan islændinge formår at være samtidigt ,,individual“ og ,dividual“- -,sig selv“ og ,den anden“. Jeg argumenterer for, at dette er nøglen til at forstå spændingsfeltet mellem hypermodernitet og den stædige fastholdelse af traditioner, som mange har iagttaget i det islandske samfund. 

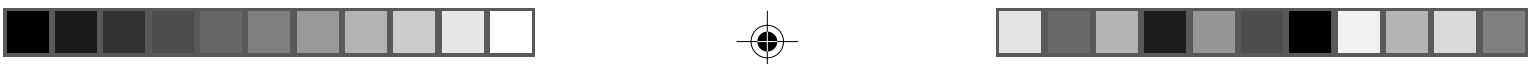

Pótt pú langförull legðir

Sérhvert land undir fót,

Bera hugur og hjarta

Samt píns heimalands mót.

(Selv om du rejser langt

og til ethvert land

er dine tanker og dit hjerte

formet af dit hjemland).

Stephan H. Stephansson

\section{Islandsk entreprenørskab}

Mange danskere var overraskede, da den islandske forretningsmand Jón Ásgeir Jóhannesson købte Magasin du Nord i 2004. At en islænding pludselig ejede et af de danske velstandssymboler var svært at stemme overens med det islandske samfunds størrelse på kun 300.000 indbyggere og dets tidligere tilhørsforhold til det danske rigsfællesskab. Jón Ásgeir Jóhannesson er formand for investeringsfirmaet Baugur Group, og siden erhvervelsen af Magasin har firmaet udvidet sine aktiviteter igennem opkøb af firmaer inden for især dansk og engelsk detailhandel (fx Illum og Merlin, Goldsmiths og Hamley's), etablering og køb af investeringsfirmaer i fast ejendom (fx Keops, FL Group og Atlas Ejendomme) og etablering af telefoni- og medievirksomhed som fx firmaet 365, der i Danmark udgiver Nyhedsavisen. De udenlandske firmaer, som er i Baugur Groups hænder, har i alt 75.400 ansatte, og Baugur Groups samlede aktiver var i december 2005 1,33 milliarder britiske pund, mens deres omsætning var 8,7 milliarder pund (Baugur Group 2006).

Baugur Group er kun ét eksempel på islændinge, der de sidste par år er begyndt at investere dristigt på det globale marked. Andre er Avion Group, Bakkavör og en masse små firmaer og enkelte entreprenører, for hvem det islandske marked er blevet for lille. Desuden er islandske banker efter deres privatisering i 2004 for alvor begyndt at etablere sig i Europa. Der er tale om en omsætning på mange milliarder kroner, og islandske forretningsmænd og entreprenører har i udlandet skabt det samme antal job, som hele det islandske arbejdsmarked omfatter.

Moderniteten og hypermoderniteten har medført samfundets „,atomisering“" (Tambiah 1990:151) og en ændret forståelse af kapital. Marilyn Strathern har i sin artikel „Cutting the Networks“ fra 1996 påpeget, at moderniteten har ført til, at euroamerikanerne adskiller kapital og ejendom fra person og krop. En euroamerikaner kan godt eje noget eller være „besiddende“, men opfatter ikke sig selv som ejendom. Strathern belyser den vestlige opfattelse om krop og kapital i kontrast til bamiléké-folket fra det vestlige Cameroun og de høvdinge blandt dem, der er forretningsmænd. Høvdingene kan beskrives som levende sparegrise 

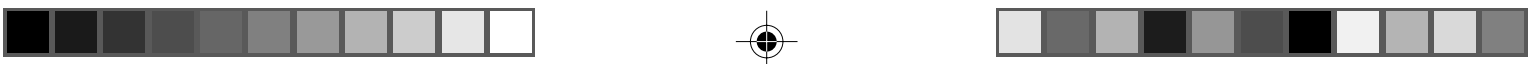

for efterkommere. De anses for at have en overflod af blod i sig, overført til dem fra deres forfædre. For bamiléké-folket står blod som metonym for overførbar livsessens, men kun når det strømmer igennem de personer, der tager „fadertitlen“. En arvtager skal gå igennem et ritual, som omdanner hans krop til slægtsgruppens „,sparegris“. Ritualet rummer blod og sæd sammen med træ og olie, som også er hans ejendom. Dette danner „boet“ for slægtsgruppen. Høvdingen har ansvar for at varetage „,boet“" og bliver en slags beholder: en „,sparegris“. Opfattelsen af kroppen som beholder tillader høvdingen at nægte krav fra slægtninge i sin kommercielle virksomhed, mens han fortsat kan regne med deres støtte, da det er fra ham, at fremtidig velstand vil komme (op.cit.:517).

I Island er derimod krop og kapital adskilt i lighed med andre vestlige samfund. Kapital strømmer frit og hurtigere end nogensinde, uden at den integreres i en person eller en krop. Bevægelsen af kapital indebærer i de fleste tilfælde dens akkumulering: Køb, omstrukturering og salg skaber - når alt går godt - mere kapital. At kroppen og personen anses for at være adskilt fra ejendom, fra slægtninge og samfundets øvrige medlemmer, understreges i den islandske politiske diskurs og i medierne. Her skildres hovedaktørerne i forretningsverdenen først og fremmest som individer. Det er entreprenøren, som står centralt, og i næsten alle tilfælde er entreprenøren et mandligt individ, som med stor gennemslagskraft og uden angst for risiko erobrer kapital, der kan producere overskud, sådan at nye investeringer muliggøres. Politikere og medier anvender succeshistorier om enkelte individer og opkøb af symboltunge firmaer for at styrke myteskabelsen og skabe heltefigurer. ${ }^{2}$

\section{Innovative helte: Stregkoder og en sparegris}

Jón Ásgeir Jóhansson er en sådan entreprenør og heltefigur. Som sagt står han som formand for Baugur Group for opkøbet af Magasin i Danmark. Jón Ásgeir (i Island omtaler man sjældent personer ved deres efternavn) påbegyndte sin forretningskarriere som 21-årig. Han blev udskrevet af Verslunarskóli (the Commercial College of Iceland er skolens officielle engelske navn) og fik sammen med sin far ideen at starte et supermarked med billige varer efter Aldi-, Nettoog Fakta-modellen. De lånte 700.000 islandske kroner i banken (omkring 58.000 $\mathrm{kr}$.), gav deres supermarked navnet Bónus og valgte en sparegris som logo.

Den første butik åbnede torsdag den 6. april 1989 kl. 12 i Reykjavík. Butikken var på 400 kvadratmeter, og tre medarbejdere stod for salg og indkøb af omkring 800 dagligvarer. Islændingene kunne dog ikke købe kød eller kødvarer i Bónus, og det var ikke muligt at betale med kreditkort. Der handledes kun i kontanter, da det ellers ville have betydet en forhøjelse af prisen, og butikken ville sikre kunden 

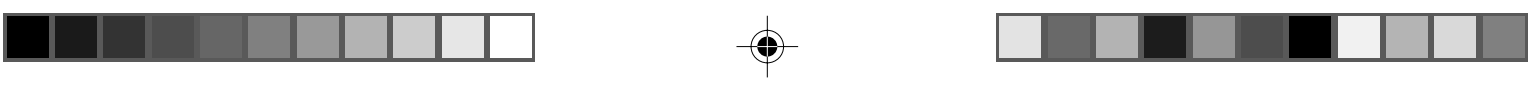

en pris, som lå omkring $10 \%$ under priserne hos de andre supermarkeder (Morgunblaðið 1989).

Den daglige omtale dengang, men især nu 18 år senere, fremhæver det innovative i etableringen af Bónus-supermarkedet. Det handler om to entreprenører, Jón Ásgeir og hans far (dengang ville man have sagt Jóhannes Jónsson og hans søn), som har bygget en supermarkedskæde - og senere et kapitalimperium - op helt fra bunden. Jón Ásgeirs far havde været butikschef for det islandske slagteriselskab, men der var ikke tale om familiekapital. Rygterne siger, at Jóhannes Jónsson var arbejdsløs på det tidspunkt, hvor ideen om Bónus-supermarkedet tog form.

Det innovative var, ud over supermarkedets enkle indretning og få medarbejdere, først og fremmest indførelsen af stregkodesystemet Datachecker. Dette gjorde arbejdsprocessen betragteligt mere effektiv: Navnene på varerne blev koblet til priserne, og ved kassen blev varerne registreret på den måde, som vi alle kender i dag. Ikke nogen indtastning af prisen, men en simpel bevægelse, hvorved stregkoderne på varerne aflæses. Et lille bip forsikrer både medarbejderen og kunden om, at varen er tjekket ud og kommet på kundens regning. Stregkoderne kobledes til et registreringssystem på lageret, sådan at man kunne få et hurtigt overblik over, hvilket indkøb man skulle foretage (Morgunblaðið 1996, 1997a). Denne nøjagtige registrering gjorde, at logistikken kunne effektiviseres, og at man kunne klare sig med et mindre antal medarbejdere. Egentlig kan man sige, at indførelsen af stregkoden har været ansvarlig for, at Magasin i dag er på islandske hænder.

I de følgende ti år udvidede Bónus sine butikker og sit vareudvalg, og langsomt byggede virksomheden et overskud op. Da den lille kundekreds, som et samfund på 300.000 indbyggere kan byde på, var opnået, lå vækstmulighederne ikke så meget $\mathrm{i}$ at åbne flere butikker. Derfor forhøjedes aktivitetsniveauet på andre planer omkring 1997. Ved siden af dagligvarer tilbød Jóhannes og Jón Ásgeir mulighed for at købe charterrejser til solrige steder. Avisen Morgunblaðið spøgte med det og afsluttede deres artikel om „Bónus-nyheden“ med: „Eitt brauð, tvo lítra af mjólk, vanilludropa og tvo miða til Benidorm ... takk fyrir“" (Et brød, to liter mælk, vaniljedråber og to flybilletter til Benidorm, tak) (Morgunblaðið 1997a).

Som Fredrik Barth har udpeget i sin velkendte artikel „Economic Spheres in Darfur“ fra 1967, handler entreprenørskab ikke kun om evnen til at kunne få øjnene op for nye forretningsmuligheder, fx ved at forbinde to tidligere adskilte økonomiske sfærer. Det indebærer også at udfordre etablerede kulturelle værdier og praksisser i samfundet, hvori entreprenøren opererer. Jón Ásgeir og hans far udfordrede igennem deres forretningsaktiviteter den islandske handelslovgivning og skattepolitik. De to entreprenører afprøvede fleksibiliteten af reglerne, når de 

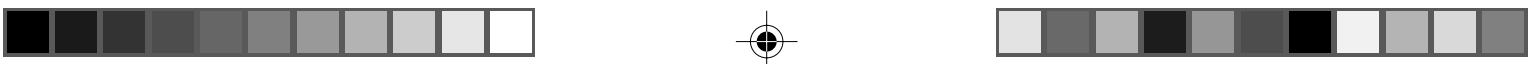

købte varer ind i udlandet. Et lille eksempel er deres salg af chokoladepastillerne M\&M's, som den islandske stat straks forbød, da M\&M's indeholder et farvestof, som den islandske lovgivning ikke godkendte. Efter Bónus havde taget M\&M's fra hylderne i en kort overgang, valgte de at begynde salget af dem igen. De to entreprenørers argument var, at regeringen selv solgte M\&M's i sine skattefrie butikker i den islandske internationale lufthavn Keflavík, og hvorfor skulle M\&M's kun være opnåelig for dem, som havde råd til at rejse (Morgunblaðið 1997c).

Hensynet til den almindelige islændings pengepung fremhævedes ofte, når Bónus-entreprenørerne forsøgte noget nyt. I 1997 kritiserede Jón Ásgeir fx prisen, som befolkningen skulle betale for grønne peberfrugter. Han fremkom med oplysninger i avisen om, at indkøb og import af disse grøntsager kun kostede 298 islandske kroner pr. kilo, men at toldafgiften hævede prisen op til næsten $800 \mathrm{kr}$. pr. kilo, og at regeringen puttede differencen i lommen. Han omtalte regeringen som landbrugets mafia og ansøgte om undtagelse for toldafgift ved Landbrugsministeriet for at få lov til at importere rød og gul peber fra Holland (Morgunblaðið 1997b). Det er disse små konflikter og afprøvning af love og skatteregler, der i tidens løb formindsker formelle restriktioner ved handlen med udlandet og ændrer politikernes og forbrugernes holdning.

Bónus' mål at kunne tilbyde kunderne Islands laveste pris på dagligvarer gennem effektivt indkøb i udlandet gjorde, at de i 1999 afprøvede sig uden for Islands grænser. De etablerede Bonus Dollar Stores i Amerika og overlod ledelsen til Jim Schaefer, en amerikaner. Bonus Dollar Stores drev 19 butikker i Florida, og målet var at fordoble dette. For at styrke butikskæden købte de Bills Dollar Stores, et firma, der var gået konkurs. En af Islands banker, Kaupping, som har kontor i New York, tilegnede sig en aktieandel på 35,7 \%. Fire år senere, i 2003, var islændingene nødsaget til at trække sig tilbage. Bonus Dollar Stores have store tab, og med den uheldige investering tabte banken Kaupping mange millioner. En dyr lærestreg var Jón Ásgeirs reaktion, men mens de trak sig tilbage fra Amerika, udvidede de deres opkøb af detailhandel i England, hvor de havde åbnet kontor i 2002 (Morgunblaðið 2003b). Efter forskellige succeshistorier i England vendte de sig mod Danmark og opkøbte Magasin i 2004.

\section{„Islændingen“}

Da den islandske globale handelsrejse er ved at være et par år gammel, dukker de første analyser af succeshistorierne op. ${ }^{3}$ Diskussionerne handler om, hvordan islændinge $e r$ i forhold til andre europæere, og hvad de gør anderledes i deres forretninger og investeringer. Hypoteserne er mangfoldige: Islændingenes lange arbejdsuge (uden at man tager højde for forholdet mellem tid og udbytte) og det 

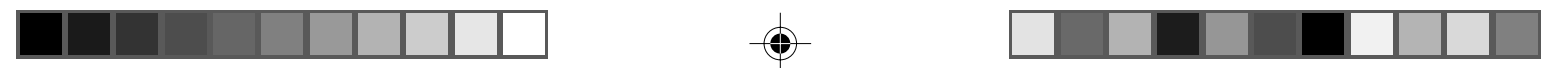

faktum, at unge islændinge vælger at tage deres kandidat- og ph.d.-uddannelse ved anerkendte universiteter i udlandet (Jón Ásgeir er ikke en af dem). Det sidste skulle forankre deres eventuelle fremtidige forretningsinitiativer i solid viden om førende økonomiske teorier og det globale markeds dynamik. Dertil øger studier ved et udenlandsk universitet bevidstheden om, at verden består af forskellige forretningskulturer, og det giver de fremtidige akademiske forretningsmænd et stort internationalt netværk. Forretningsmænd, som jeg har talt med, fremhæver desuden, at det islandske samfund er en rigtig god skole. Samfundet er kendetegnet ved en stor kompleksitet, men er på grund af størrelsen overskueligt. Island byder dermed på muligheden for at forstå komplekse processer og relationer, som man i andre europæiske lande finder i så stor en skala, at det er svært at få øje på strukturer og sammenhænge.

Dog er det især islændingenes særpræg som folkeslag, der er centralt i mange analyser, medierne og den politiske diskurs. For eksempel citerer Pór Sigfússon, formand for det islandske forsikringsselskab Sjóva, Johannes Møllehave i sin bog Straumhvörf fra 2005. Møllehave udtalte sig om islændinge i den islandske avis Morgunblaðið på følgende måde: „I er så stærke, I tror på livet, I er fulde af energi, interesse og arbejdslyst, I er utrolig gæstfrie og besidder en dyb forståelse for andre mennesker. Og så er I verdensborgere, de fleste islændinge rejser ud i verden“" (Morgunblaðið 2003a). Det er udrejsen, som fremhæves og præsenteres på en forførende måde i de islandske medier og politik. Udrejsen bliver essensen $i$ islændingenes identitet, og her er det vikingemetaforen, som gang på gang benyttes. De unge islandske entreprenører beskrives som den nye generation vikinger, der uden angst og med stor gennemslagskraft erobrer verden. Ordet útrás er den islandske betegnelse for islændingenes nuværende globale handelsrejse. Begrebet anvendes også om Islands landnamperiode (ca. 870-930), hvor det refererer til forfædrenes udrejse med det mål at finde nyt land i stedet for at underkaste sig den norske konge Haraldr hinn hárfagri, der fratog storbønder deres jord.

Appadurai argumenterede i 1988 for, at der er tre udviklingskurser i den vestlige tankegang. For det første essentializing, som betyder, at et samfunds kompleksitet reduceres til nogle specifikke kulturelle kendetegn, som bliver til folkeslagets „essens“. For det andet exoticizing, som vil sige, at forskellen mellem „os“ og „dem“ bliver til det eneste kriterium for sammenligning, og til sidst totalizing, det at gøre specifikke kendetegn ved et samfunds tankegang eller praksis ikke kun til dets essens, men også til dets totalitet. Disse tre udviklingskurser gælder - i hvert fald i entreprenørskabssammenhæng - også for islændingene. Entreprenøren står for ,islændingen“. En samtale, som jeg havde med en islandsk taxachauffør i december 2006, kan belyse dette. 

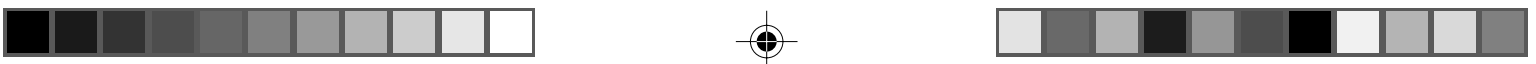

Taxachaufføren kørte mig til den islandske investeringsbank Kaupping og ville vide, hvad jeg skulle der. Jeg fortalte ham, at jeg forsker i útrás, islændingenes globale handelsrejse. „Ved du, hvorfor vi er så dygtige til útrás?“, spurgte taxachaufføren mig. „Nej, hvorfor er det egentlig sådan?“, spurgte jeg. Han sagde: „Við erum óhrcett fólk (Vi er et frygtløst folk).“ „Hvorfor?“, ville jeg gerne vide, ,hvorfor har I ikke angst?“ Han svarede: „Du skal gå lang tid tilbage for at kunne forstå det. Postbude fx skulle bevæge sig på ekstremt farlige veje. Måske havnede de i en snestorm. Men uanset hvad så klarede de det. For at give dig et eksempel: Da jeg engang var på jagt, havnede jeg i en snestorm. Jeg kunne slet ikke se noget [...], men jeg vidste, i hvilken retning jeg skulle gå. Uanset hvad der sker i vores liv, fortsætter vi med at leve. Vi er ikke bange, da det ikke er vigtigt, hvad der sker. Livet vil fortsætte.“

Taxachaufføren reducerer succesen bag den islandske útrás til ideen om, at „vi er et frygtløst folkeslag“ (essentializing), hvori der ligger et implicit „mens I er bange" (exoticizing), og senere en totalisering ved at fremhæve, at mod, som er den islandske folkesjæls essens, findes i forretningsmænd, i postbude og i ham selv.

\section{Det individualistiske og innovative selv}

Den islandske selvopfattelse, som kommer frem i den nuværende folkelige og politiske diskurs og $i$ handelsdiskursen, er kendetegnet ved ideen om, at der findes kontinuitet i „folkesjælens“ essens, som udtrykkes i vikingemetaforen. På samme tid identificerer befolkningen sig med innovative individer, som bryder med gamle strukturer og magtrelationer. Bónus-historien, som jeg har beskrevet ovenfor, viser, hvordan to entreprenører prøver sig frem ved at udfordre etablerede tankegange og praksisser. De introducerer et supermarked med billige varer, effektiviserer deres arbejdsmetoder ved at inddrage ny teknologi og udfordrer regeringen til at tage stilling til problemstillinger, som ikke før er blevet formuleret. De bryder med ideen om, at Island er økonomisk afhængigt af fiskeri og rodfæstet $\mathrm{i}$ landbrugskultur (Gurevich 1969; Hastrup 1981; Gunnlaugsson 1988; Hálfdanarsson 1995) ved at bevæge sig ud over landets grænser for at opdyrke nye forretningsområder og muligheder for at gøre deres handel mere effektiv. De islandske kulturelle rødder er flyttet fra land til hav: Det er den søfarende viking og ikke den jordejende viking, som er kommet til at stå centralt.

Den folkelige diskurs om disse innovative helte inddrager forfædrene, men ikke slægtninge. Jón Ásgeir Jóhannesson omtales ikke i lyset af særlige kendetegn ved hans slægt. Det er bemærkelsesværdigt, da slægtskabsrelationer er et af de store emner i islændingenes daglige samtaler. Til trods for vikingemyten er fokus 

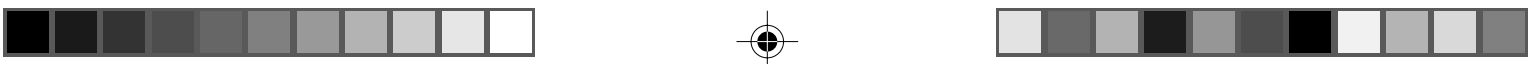

også her på den nye samfundsorden. Islands nye generation af forretningsmænd bryder med gamle strukturer, hvor kapital og magt i århundreder har været $\mathrm{i}$ hænderne på få slægter. Den folkelige diskurs dannes omkring narrativer, som bekræfter, at handelsimperiet er bygget op på eget initiativ og individets kræfter. Forskellige personer kunne fortælle mig, at Jón Ásgeir som dreng solgte popkorn på gaden, og at hans far var arbejdsløs, mens aviser skriver, at han lejede sit flotteste legetøj ud til venner, og at han ikke ville være millionær, men milliardær.

Det betyder dog ikke, at individualisme er noget nyt i Island, som kun er opstået med opkomsten af global kapitalisme og hypermodernitet. Islands historie er ikke en historie om begivenheder, men om personer. Den islandske billedhugger Einar Jónsson (1875-1954) har meget rammende udtrykt individets centrale rolle i de sociale forandringsprocesser, især i sit værk om Jón Sigurðsson, den islandske uafhængighedshelt. I mindesmærket Brautrydjandi (Banebryderen) fra 1911 afbilder Einar Jónsson Jón Sigurðsson som en kæmpe, der flytter store basaltsøjler fra en vej. „Folket“ er meget mindre i format og har alle det samme udtryk og udseende. Det forbliver en anonym masse, der passivt venter på, at helten åbner vejen ind til fremtiden. Spændingen mellem den individualistiske person på den ene side og den relationelle og sociale person på den anden side har faktisk kendetegnet samfundet i meget lang tid.

\section{Det islandske sociale selv: Navne og slægtninge}

Islændingenes sociale selv kommer stærkt til udtryk i måden, hvorpå islændinge navngiver børn. For at inddrage de to entreprenører igen: Jón Ásgeir hedder Jóhannesson til efternavn. Som jeg har nævnt før, hedder hans far Jóhannes Jónsson og hans mor er Ása Karen Asgeirsdóttir. Jón Ásgeirs farfar hedder Jón Elías Eyjólfsson og Jón Ásgeirs søster er Kristín Jóhannesdóttir. Jón Ásgeir har været gift med Linda Margrét Stefánsdóttir og har tre børn med hende: Ása Karen, Anton Felix og Stefán Franz. Navngivning i denne familie er blot et eksempel på det islandske patronymiske navngivningssystem, hvor børnenes efternavn afledes af den genitive form af deres fars fornavn, tilføjet suffikset son (søn) eller - dóttir (datter). Jón Ásgeir har efternavnet Jóhannesson og hans søster Jóhannesdóttir, da deres far hedder Jóhannes. Kun få islandske familier har i dag lov at benytte et cettarnafn (slægtsnavn).

Navne positionerer børn i et socialt netværk, ofte et slægtskabsnetværk. Da det islandske samfund er kendetegnet ved et bilateralt slægtskabssystem, giver forældrene deres børn fornavne efter såvel deres matrilineære som patrilineære bedsteforældre (Tebbenhoff 1985:569). Som vi kan se i ovennævnte eksempel er navnet Jón Ásgeir sammensat af bedstefædrenes navne: Jón Ásgeirs farfar hed- 

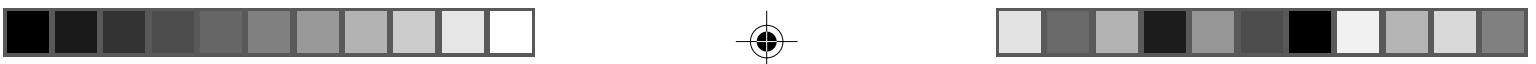

der Jón og hans morfar Ásgeir. Jón Ásgeir og Linda Stefánsdóttir har også valgt at give deres børn navne fra børnenes bedsteforældre. Deres ældste datter er kaldt Ása Karen efter Jón Ásgeirs mor og deres yngste søn Stefán efter Lindas far.

Hvor vigtigt det er og har været at videregive bedsteforældrenes navne og derved beholde navnene i familien, kommer især til udtryk, når man laver en analyse af islandsk navngivning i første halvdel af 1800-tallet, da børnedødeligheden var høj. Søskende fik ofte det samme navn, da navnet, i det tilfælde de skulle dø, stadigvæk kunne beholdes i familien. Dette kan delvis forklares med hensyn til overførsel af ejendom, rettigheder og pligter mellem generationer. Der ligger dog også en mere kosmologisk forklaring bag, nemlig den at „,navnet aldrig må dø“ (Nuttall 1994). Navngivning er en måde, hvorpå de afdødes minde vedligeholdes i det levende samfund og hermed sikrer samfundets fortsættelse. Dette kommer især til udtryk i en i nutidens samfund udbredt navnepraksis, som indebærer, at en afdød opsøger en gravid kvinde (eller hendes slægtninge eller venner) i (hendes) drømme. Denne praksis, som kaldes for að vitja nafns, er parallel med og nogle gange dominerende i forhold til den praksis at opkalde et nyfødt barn efter en af bedsteforældrene.

\section{Að vitja nafns}

I Sydisland viste en ung pige med navnet Sigrún sig i adskillige gravide kvinders drømme, efter at hun omkom med sin kæreste i en lavine. Helga Karlsdóttir, som jeg arbejdede for på dette tidspunkt, fortalte mig, at dette også var tilfældet, da hun var gravid med sin ældste datter. Sigrún havde før vist sig i Helgas drømme, men drømmene vendte oftere tilbage under graviditeten. Da Helga drømte om Sigrún den første gang under graviditeten, fortalte hun drømmen til sin mor, der var overbevist om, at Sigrún ville give sit navn til Helgas kommende barn. Helga og hendes mand var ikke sikre, men da Sigrún blev ved med at vise sig i Helgas drømme, fik deres ældste datter navnet Sigrún. Efter dette ser Helga kun Sigrúns hoved i en drøm. Helga synger og er glad. Dette anses for et tegn på, at det var rigtigt, hvad de gjorde.

At en afdød viser sig i en drøm for at videregive sit navn til et barn kaldes på islandsk for að vitja nafns. Að vitja betyder at opsøge og nafns (gen. af nafn) navnefælle. Med andre ord opsøger de afdøde deres kommende navnefælle, og nogle gange viser drømmen meget tydeligt, at det handler om en afdød, som flytter tilbage til den levende verden igennem navngivning. Den gravide kvinde kan drømme om en afdød, der står foran sig med sine ejendele, og hun hører hende eller ham sige: „Nu flytter jeg ind hos dig.“ 

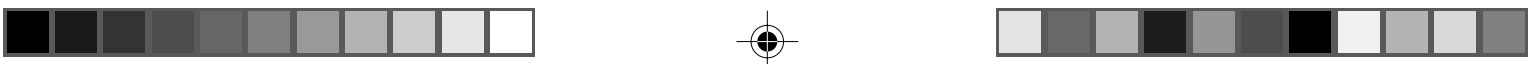

Að vitja nafns kan anvendes strategisk af især gravide kvinder, hvis de hellere vil give deres barn et andet navn end bedsteforældrenes. Der er nemlig kun få fædre, der nægter at følge den afdødes ønske. Dette ville kunne udsætte det nyfødte barn for fare. Der cirkulerer adskillige beretninger om, at et barn er blevet sygt, fordi forældrene ikke imødekom en afdøds ønske om at give barnet sit navn. Að vitja nafns er dog især et udtryk for kosmologiske forestillinger om, at samfundet kun kan fortsætte, når en del af den afdøde igen integreres blandt de levende. Denne del kan være bestemte personlige træk, der videregives med navnet, som følgende eksempel illustrerer.

I 2006 besøgte jeg en kvinde, der under sin graviditet havde drømt om en afdød veninde. Hendes veninde havde vist sig adskillige gange i hendes drømme. Da hun var i gang med at fortælle mig sin historie, tilkaldte hun sin datter, som havde fået den afdødes navn. Pigen kom ind ad døren og blev omfavnet af sin mor, mens moren sagde til mig: „De ligner hinanden. De har samme udseende og livlige personlighed.“ De navne, som videregives igennem praksissen að vitja nafns, stammer oftest fra afdøde, som ikke har „bedsteforældrestatus“. Det vil sige de personer, der ikke har haft mulighed for at videregive deres navn, og dermed en del af deres personlighed, ved at have fået børn. ${ }^{4}$

Et navn og et barn passer ikke altid til hinanden. Kommende forældre venter ofte med at give deres barn et navn, da de først vil se, om navnet, som de har i tankerne, også passer til barnets personlighed. Det islandske udtryk barnið kafnar undir nafnið (barnet kvæles af sit navn) bruges fx, når et barn har fået et navn fra en meget anset og respekteret person, og barnet ikke lever op til navnets fordringer. Dette betyder, at navngivning er et forsøg på at integrere to i princippet særskilte identiteter. I de tilfælde hvor integrationen af disse identiteter ikke lykkes, bærer barnet navnet videre, uden at det integreres i kroppen, men det videregives til den næste generation. Dette illustrerer, hvorledes man i Island på samme tid kan være „sig selv“ og den ,anden“.

\section{Den dividuelle og individuelle islænding}

Kritikken af en skelnen mellem det sociale eller ,dividuelle“, ikke-vestlige selv og det moderne individualistiske selv udfolder sig ofte igennem analyser, som påpeger det rationelle eller individualistiske selv i relationelle eller "holistiske“ samfund (Dumont 1985). Ideen om, at der ligger en individualistisk personopfattelse bag handlinger, såsom det at investere i det globale marked, tager vi for givet. Internationale forretningstransaktioner antages at bygge på rationelle beslutninger taget af resultatorienterede personer, hvis kroppe ikke ,indlejrer" kapital, hvorved kapital kan strømme frit. Det islandske samfund viser, hvordan ikke kun 
den dividuelle og den individuelle personopfattelse sameksisterer, men desuden, hvordan man kan være sig selv såvel som den anden. I islandske kosmologiske forestillinger er tilbagevenden af (en del af) de afdøde blandt de levende igennem navngivning, eller minde på anden måde, yderst vigtigt. I hver person er der derfor, i princippet, minde eller personlighedstræk fra afdøde. Afdøde behøver ikke nødvendigvis at være slægtning, når navngivningen har fundet sted igennem að vitja nafns. Alt dette betyder dog ikke, at islændinge handler på basis af, hvordan forfædrene skulle have handlet, men at man bærer „fortidens ånd“ med sig, uden at den står i vejen for, at man skaber sig en position i samfundet bygget på egne kræfter og initiativer. Overbevisningen om, at man efter døden overlever i navn eller minde hos dem, som kommer efter, kan have indflydelse på risikovillighed i det islandske samfund. Ligesom taxachaufføren sagde: Livet vil fortsætte, uanset hvad der sker.

\section{Konklusion}

Dumont skrev, at der er to typer samfund: samfund, hvor individet er altafgørende, og som man kan karakterisere ved individualisme, og holistiske samfund, hvor helheden er altafgørende (Dumont 1985:94). Ifølge Dumont kan et medlem af et holistisk samfund kun udfolde sin individualistiske side ved at bevæge sig uden for samfundet. Dumont tager det indiske samfund som eksempel og skriver:

En 'renouncer' er selvtilstrækkelig, kun optaget af sig selv. Hans tænkemåde er tilsvarende det moderne individs, dog er der en grundlæggende forskel: Vi lever i den sociale verden, han lever uden for denne. Derfor kalder jeg den indiske 'renouncer' for et individ-uden-for-verden. Sammenlignet er vi individer-iverden (Dumont 1985:94-5, min oversættelse).

Min analyse af islandske personopfattelser har vist, at islændinge ikke nødvendigvis behøver at bevæge sig uden for samfundet, hvis de som „dividuelle“ islændinge vil fremhæve deres individualisme. Muligheden for at være såvel ,sig selv“ som „den anden“ gør, at man kan være både individualistisk og relationel. Dette udfordrer den ofte statiske opfattelse af den vestlige person.

\section{Noter}

1. Det engelske ord entrepreneurship oversættes i mangel af bedre til entreprenørskab.

2. Forholdet mellem de islandske politikere og entreprenører er dog yderst komplekst og modsætningsfuldt.

3. At man også kan lære af at analysere sine fejl er noget, som man meget senere er begyndt at 
fokusere på. Den 7. februar 2007 udkom en første rapport, hvor fejltagelserne i den islandske globale handelsrejse analyseres.

4. For en analyse af að vitja nafns i forhold til kosmologiske forestillinger, se Heijnen (2005).

5. Dumont mener med „vi“ den vestlige befolkning.

\section{Litteratur}

Appadurai, Arjun

1988 Place and Voice in Anthropological Theory. Cultural Anthropology 3(1):36-49.

Barraud, Cécile, Daniel De Coppet, André Iteanu \& Raymond Jamous

1994 Of Relations and the Dead. Four Societies Viewed from the Angle of their Exchanges. Oxford: Berg.

Barth, Fredrik

1967 Economic Spheres in Darfur. I: R. Firth (ed.): Themes in Economic Anthropology. London: Tavistock Press.

Baugur Group

2006 Baugur Group’s Corporate Brochure. Reykjavík: Baugur Group.

Dumont, Louis

1985 A Modified View of Our Origins: The Christian Beginnings of Modern

Individualism. I: M. Carrithers, S. Collins \& S. Lukes (eds.): The Category of the Person. Cambridge: Cambridge University Press.

Ewing, Katherine $\mathrm{P}$

1990 The Dream of Spiritual Self Initiation and the Organization of Self

Representations among Pakistani Sufis. American Ethnologist 17(1):56-74.

Geertz, Clifford

1984 From the Natives' Point of View: On the Nature of Anthropological understanding. I: R.A. Shweder \& R.A. leVine (eds.): Culture Theory. Cambridge: Cambridge University Press.

Gunnlaugsson, Gísli Ágúst

1988 Family and Household in Iceland 1801-1930. Uppsala: Acta Universitatis Upsaliensis.

Gurevich, A. Ya.

1969 Space and Time in the Weltmodell of the Old Scandinavian Peoples. Mediaeval Scandinavia 2:42-53.

Friedman, Jonathan

1997 Ecological Consciousness and the Decline of 'Civilizations'. The Ontology, Cosmology and Ideology of Non-Equilibrium Living Systems. Paper præsenteret på sessionen Culture/Power/History/Nature: Papers in Honor of Roy A. Rappaport, $96^{\text {th }}$ Annual Meeting of the American Anthropological Association, 19.-23. november, Washington, D.C. [http://wwww.soc.lu.se/san/papers/ rappaport.htm].

Hálfdanarsson, Guðmundur

1995 Social Distinctions and National Unity: On Politics of Nationalism in Nineteenth Century Iceland. History of European Ideas 21(6):763-79. 
Hastrup, Kirsten

1981 Cosmology and Society in Medieval Iceland. A Social Anthropological Perspective on World-view. Ethnologia Scandinavica 11:63-78.

Heijnen, Adriënne

2005 Dream Sharing in Iceland. Århus: Aarhus Universitet.

Hornborg, Alf

$1998 \quad$ Ecological Embeddedness and Personhood. Have We Always been Capitalists? Anthropology Today 14(2):3-5.

Mageo, Jeanette Marie

2003 Dreaming and the Self: New Perspectives on Subjectivity, Identity, and Emotion. New York: State University of New York Press.

Morgunblaðið

1989 Verslun Bónus. Ný kjarakaupaverslun tekur til starfa. Morgunblaðið,

Viðskiptablað, 6. april.

1996 Rafrænar hillumerkingar í Bónus. Morgunblaðið, Neytendur, 8. august.

1997a Bónus hefur sölu á sólarlandaferðum. Morgunblaðið, Neytendur, 6. marts.

1997b Skýringin háir tollar og slæm birtuskilyrði, Morgunblaðið, Neytendur, 15. maj.

1997c Bónus selur aftur M \& M sælgæti. Morgunblaðið, Neytendur, 24. maj.

1997d Bónus með fyrstu rafrænar hillumerkingar. Morgunblaðið, Viðskiptablað 12. juni.

2003a Yfirborðsmennska mín ristir aldrei djúpt. Morgunblaðið, Sunnudagsblað, 27. april.

2003b Miljarða tap af verslunarrekstri í Bandaríkjanum. Morgunblaðið, Netblað, 31. juli.

Nuttall, Mark

1994 The Name Never Dies: Greenland Inuit Ideas of the Person. I: A. Mills \& R. Slobodin (eds.): Amerindian Rebirth: Reincarnation Beliefs Among the North American Indians and Inuit. Toronto: University of Toronto Press.

Oxfeld, Ellen

1992 Individualism, Holism and the Market Mentality: Notes on the Recollections of a Chinese Entrepreneur. Cultural Anthropology 7(3):267-300.

Spiro, Melford E.

2003 Is the Western Concept of the Self 'Peculiar' within the Context of the World Cultures? Ethos 20(3):107-53.

Strathern, Marilyn

1988 The Gender of the Gift: Problems with Women and Problems with Society in Melanesia. Berkeley: University of California Press.

1996 Cutting the Network. The Journal of the Royal Anthropological Institute 2(3):517-35.

Tambiah, Stanley Jeyaraja

1990 Magic, Science, Religion and the Scope of Rationality. Cambridge: Cambridge University Press.

Tebbenhoff, Edward H.

1985 Tacit Rules and Hidden Family Structures: Naming Practices and Godparentage in Schenectady, New York 1680-1880. Journal of Social History 18(4):567-85.

Pór Sigfússon

2005 Straumhvörf. Útrás íslensks viðskiptalífs og innrás erlendra fjárfesta til Íslands. Reykjavík: Mál og Menning. 
